DOI https://doi.org/10.30525/978-9934-26-074-2-60

\title{
EFFECTS OF INADMISSIBILITY OF EVIDENCE: THEORETICAL AND LEGAL FRAMEWORK
}

\author{
Drozd V. H. \\ Doctor of Law, Professor, Honoured Lawyer of Ukraine, \\ Head of the $3^{\text {rd }}$ Research Department of Research Laboratory of Problems \\ of Legal and Organizational Support of the Ministry Activities \\ State Research Institute of the Ministry of Internal Affairs of Ukraine \\ Kyiv, Ukraine

\section{Havryliuk L. V.} \\ Candidate of Juridical Sciences, \\ Senior Researcher at Research Laboratory of Problems of Legal \\ and Organizational Support of the Ministry Activities \\ State Research Institute of the Ministry of Internal Affairs of Ukraine \\ Kyiv, Ukraine
}

\author{
Havryliuk V. V. \\ Bachelor's Degree Student \\ National Academy of Internal Affairs \\ Kyiv, Ukraine
}

Criminal procedure, as an activity, is cognitive. Therefore, the actors responsible for proving under the Art. 92 of the Criminal Procedure Code, with a view to taking a correct and well-founded decision in a case, seek to establish a reliable picture of the past event, to clarify all the circumstances and to establish the truth. It is on the basis of the totality of evidence, collected in criminal proceedings, the investigators, guided by the law and the professional legal awareness, during the pre-trial investigation, and the judges, during the trial, conclude that a crime has been committed or that there is no evidence of it, that the accused is guilty or innocent of the crime, that the facts relevant for the proper resolution of the criminal case have been established [1, p. 3]. Accordingly, every procedural decision taken by the investigator during the pre-trial investigation usually has legal effects that can be grouped into positive ones, enabling to establish all the facts of the case and punish the guilty parties, and negative ones, leading to inadmissibility of evidence. Moreover, inadmissible evidence cannot be used in procedural decisions, nor can it be invoked by a court in judicial decisions, etc. 
The Great explanatory dictionary of modern Ukrainian language defines the concept of «effect» as what derives, follows from something, or as a result [2, p. 581]. In our opinion, a more comprehensive concept is the «intangible effect,» which is interpreted as a variety of socially dangerous effects involving damage combined with the violation of some interests of participants in public relations, protected by criminal law, which is generally not connected with physical influence on a person as a subject of public relations or influence on material objects of the outside world (goods) in respect of which public relations exist [3, p. 178]. If social relations arising in the process of proving by actors authorized by the CPC of Ukraine is the object of our study, accordingly, the legal effects of inadmissibility of evidence during the pre-trial investigation should be the revocation of the investigator's decision by the prosecutor on the basis of the evidence, as well as the impossibility of using the evidence in the proceedings. That is, inadmissibility of evidence entails legal effects that depend on its evidentiary value in criminal proceedings.

In the CPC of Ukraine, some provisions determine the powers of participants in criminal proceedings, the grounds and procedure for conducting procedural, investigative (search) and covert investigative (search) actions, and expert reports; establish the parties to criminal proceedings responsible of proving in criminal proceedings, as well as legal effects in case of noncompliance with procedural provisions by participants in criminal proceedings. Accordingly, the set of criminal procedure provisions governing the investigator's performance, such as the collecting, verification and evaluation of evidence in order to establish the facts relevant to criminal proceedings, is an element of evidence.

According to the provisions of the CPC of Ukraine, procedural, investigative (search) and covert investigative (search) actions are related to the identification, recording and verification of evidence in criminal proceedings. In particular, their essence is both cognitive and regulatory. The cognitive character is determined by the cognitive techniques used by the investigator in their course. The regulatory character is the detailed guidance of the rules and conditions for their conduct, established by the criminal procedure legislation.

According to L. Loboiko's definition of the features of provisions governing investigative actions, each of their elements (hypothesis, disposition, sanction) has a certain specificity.

The hypothesis formulates a ground for an investigative action. In some cases, the law does not specify such grounds in the provision. However, this does not mean that the provision does not contain a hypothesis. 
The disposition of the concept of investigation actions set out the procedure for conducting an investigative action, its participants, the place and time of carrying it out, etc.

Sanctions of investigative actions provision are grouped according to an actor whom they are addressed to. The first group includes those addressed to the investigator or other official conducting the proceedings, such as criminal legal ones and criminal procedural ones (revocation of procedural decisions taken on the basis of information obtained as a result of unlawful investigative actions). The second group includes those addressed to other participants in the investigation [4, p. 188].

That is, the regulatory force of the law means that legal provisions are generally binding rules of conduct established, authorized and enforced by the State, and the system of legal provisions constitutes an objective law. Accordingly, the provisions of criminal procedure oblige, prohibit, establish or permit rules of conduct, thus organizing social relations.

Therefore, the existence of provisions - the regulatory force of law - is one of its basic and necessary features. With regard to the provisions of criminal procedure, they will be a regulator of relations between parties to criminal proceedings if they are able to react to the negative effects of the performance of persons, conducting initial inquiries and pre-trial investigations. Otherwise, this function cannot be implemented. Accordingly, we advocate the perspective that inadmissibility of evidence is an important criminal procedure sanction applied in case of establishing criminal procedure violations in the course of taking and recording evidence, as a means of reaction by the person conducting the initial inquiry, the investigator, the prosecutor, the judge and a court to violations found. It entails negative legal effects, the range thereof is due to the materiality of inadmissible evidence in criminal proceedings and the powers of the assessor at an appropriate stage of inadmissibility of evidence [5, p. 186].

\section{References:}

1. Hroshevyi Yu.M., Stakhivskyi S.M. (2006) Evidence and proving in criminal proceedings. Scientific and practical manual [Dokazy i dokazuvannia u kryminalnomu protsesi. Naukovo-praktychnyi posibnyk]. Kyiv: KNT, Fursa S.Ya., 272 p. (in Ukrainian)

2. Busel, V. T. (Ed.) (2002) Velykyi tlumachnyi slovnyk suchasnoi ukrainskoi movy [Great explanatory dictionary of modern Ukrainian language]. K., Irpin: PTF Perun, 1440 p. (in Ukrainian)

3. Kyselov I.O., Shablystyi V.V., Chorna V.O., Yakymenko L.H. (2017) Slovnyk osnovnykh kryminalno-pravovykh terminiv [Dictionary of basic 
criminal law terms]. Dnipro: Dnipropetrovsk State University of Internal Affairs, 388 p. (in Ukrainian)

4. Loboiko L. M. (2005) Kriminalno-protsesualne pravo: kurs lekysii. [Criminal procedure law: Teaching manual]. K.: Istina, 456 p. (in Ukrainian)

5. Basai N.M. (2012) Vyznannia dokaziv nedopustymymy v kryminalnomu protsesi Ukrainy: pidstavy, protsesualnyi poriadok $i$ pravovi naslidky [Inadmissibility of evidence in the criminal procedure of Ukraine: Grounds, procedural order and legal effects] (PhD Thesis), Odessa.

DOI https://doi.org/10.30525/978-9934-26-074-2-61

\title{
ПОНЯТТЯ ТА ПІДСТАВИ ВИСУНЕННЯ ПРОКУРОРОМ ДОДАТКОВОГО ОБВИНУВАЧЕННЯ В СУДІ
}

\author{
Ільюшонок О. Ю. \\ прокурор першого відділу процесуального керівництва \\ Харківської обласної прокуратури \\ м. Харків, Україна
}

Існують випадки, коли під час судового розгляду кримінальної справи з'ясовуються обставини, які викривають обвинуваченого у вчиненні ще одного або декількох злочинів, за якими обвинувачення йому не було висунуто.

Наприклад, свідки, потерпілі, сам обвинувачений, або ж інші учасники процесу надають показання, що обвинувачений вчинив умисне вбивство, а після цього погрожував вбивством очевидцям злочину у разі розголошення ними цих фактичних даних і у свідків були реальні підстави побоюватися цієї погрози, але на досудовому слідстві останні про це не повідомляли.

Для таких випадків, які тісно межують зі зміною обвинувачення прокурором у суді, але мають свою особливість, законодавець передбачив для публічного обвинувача висунення додаткового обвинувачення.

Необхідно одразу зазначити, що свого часу запровадження можливості висунення прокурором додаткового обвинувачення у суді в тому вигляді, в якому воно пропонується чинним Кримінальним процесуальним кодексом України (далі - КПК України), стало однією з його новел. I введена вона була замість інституту додаткового досудового розслідування, щоб прокурор міг виправити помилки, допущені під час слідства. Однак, на жаль, ця новела так і залишилась прогресивною новелою, яка повинна була зумовити ефективне використання часових i 